\title{
HIEGENE DAN SANITASI CUCI TANGAN PAKAI SABUN DI KELURAHAN KEBUN BUNGA KECAMATAN SUKARAMI KOTA PALEMBANG
}

\author{
Zalili Aziz \\ Aseptianova \\ Sulton Nawawi \\ Eka Haryati Yuliany \\ Program Studi Pendidikan Biologi, Fakultas Keguruan dan Ilmu Pendidikan \\ Universitas Muhammadiyah Palembang \\ Jalan A. Yani No. 13 Palembang \\ nasepti@yahoo.co.id
}

\begin{abstract}
ABSTRAK
Perilaku higiene dan sanitasi cuci tangan pakai sabun merupakan investasi kesehatan yang paling murah dan efektif untuk mencegah timbulnya berbagai penyakit. Cuci tangan pakai sabun adalah hal kecil namun berdampak besar bagi kesehatan manusia. Tujuan pengabdian masyarakat ini adalah adanya peningkatan pengetahuan, kemampuan serta peran aktif PKK, dasawisma dan masyarakat tentang higiene dan sanitasi cuci tangan pakai sabun sehingga dapat meningkatkan derajat kesehatan masyarakat. Pengabdian masyarakat ini menggunakan model partisipatif dan deskriptif kuantitatif untuk menggambarkan perilaku penduduk mengenai higiene dan sanitasi dalam menerapkan cuci tangan pakai sabun. Simpulan dalam pengabdian ini 1) Pengabdian masyarakat ini menunjukkan adanya peningkatan higiene dan sanitasi cuci tangan pakai sabun. 2) Responden menyadari bahwa dengan mencuci tangan pakai sabun dapat mencegah timbulnya berbagai penyakit. 3) Responden memahami dan mengetahui kegunaan serta waktu penting tantang cuci tangan pakai sabun.
\end{abstract}

Kata Kunci: higiene; cuci tangan; sabun; kesehatan; partisipatif 


\section{PENDAHULUAN}

Perilaku Hidup Bersih dan Sehat (PHBS) merupakan perwujudan rill paradigm sehat dalam budaya hidup perorangan, keluarga dan masyarakat yang berorientasi sehat, bertujuan ntuk meningkatkan, memelihara dan melindungi kesehatannya. Perilaku Hidup Bersih dan Sehat (PHBS) adalah semua prilaku kesehatan yang dilakukan atas kesadaran sehinga anggota keluarga atau keluarga dapat menolong dirinya sendiri di bidang kesehatan dan berperan aktif dalam kegiatan-kegiatan kesehatan di masyarakat (Elytha, 2009).

Wujud keberdayaan masyarakat yang sadar, mau dan mampu mempraktekkan PHBS mencapai 5 program prioritas yaitu KIA, Gizi, Kesehatan Lingkungan, Gaya Hidup, Dana Sehat/Asuransi Kesehatan/JPKM. Perilaku Hidup Bersih dan Sehat (PHBS) masyarakat diharapkan dapat mendukung upaya mencapai program Indonesia sehat. Salah satu Indikator dari Prilaku Hidup BErsih dan Sehat salah satunya adalah cuci tangan pakai sabun (CTPS).

Hasil yang diharapkan dari kegiatan pengabdian masyarakat ini Hal| 115 adalah meningkatnya pengetahuan masyarakat tentang pentingnya cuci tangan pakai sabun untuk mencegah timbulnya berbagai penyakit serta meningkatkan kemampuan masyarakat untuk mencuci tanga secara baik dan benar.

Badan Keehatan PBB World Health Organization (WHO) menjelaskan kedua tangan adalah salah satu jalur utama masuknya kuman penyakit ke dalam tubuh sebab tangan adalah anggota tubuh yang paling sering berhubungan langsung dengan mulut dan hidung (Megaria, dkk. 2013).

Mencuci tangan adalah membersihkan tangan dari segala kotoran, dimulai dari ujung jari sampai siku dan lengan dengan cara tertentu sesuai kebutuhan. Perilaku cuci tangan sebagai salah satu bentuk kebersihan diri sendiri yang penting. Mencuci tanga juga dapat diartikan menggosok 
dengan sabun secara bersama seluruh kulit permukaan tangan dengan kuat dan ringkas yang kemudian dibilas di bawah air yang mengalir (Kushartanti, 2012).

Berbagai riset mengatakan resiko penularan penyakit dapat berkurang dengan adanya peningkatan perilaku hidup bersih dan sehat, perilaku kebersihan seperti cuci tangan pakai sabun. Perilaku cuci tangan pakai sabun merupakan intervensi kesehatan paling murah dan efektif dibandingkan dengan intervensi kesehatan cara lainnya.

Menuci tangan pakai sabun adalah salah satu cara yang paling efektif untuk mencegah penyakit misalnya diare dan ISPA, mencuci tangan pakai sabun juga dapat mencegah infeksi kulit, mata, cacingan dan flu burung. Idealnya mencuci tangan sebaiknya menggunakan air bersih, air mengalir, sabun dan aair bersih tersebut adalah air jernih, tidak berbau dan tidak berwarna. Mencuci tangaan pakai sabun sebaiknya dilakukan pada lima waktu penting yaitu sebelum makan,s esudah buang air besar, sebelum memegang bayi, sesudah menceboki anak, dan sebelum Hal| 116 menyiapkan makanan. Cuci tangan merupakan hal yang paling umum pada masyarakat, namun memakai sabun bukanlah sesuatu yang jamak. Penggunaan sabun untuk cuci tangan lebih disebabkan alasan kotor, kebanyakan masyarakat memandang sabun hanya bermanfaat menghilangkan kotor dan bau.

Kesadaran masyarakat Indonesia untuk cuci tangan pakai sabun (CTPS) terbukti masih sangat rendah, padahal cuci tangaan pakai sabun sangat penting agar terhindar dari berbagai penyakit (Kushartanti, 2012).

Pengabdian masyarakat ini dimanfaatkan sebagai usaha promosi kesehatan mandiri seperti di Kelurahan Kebun Bunga Kecamatan Sukarami Kota Palembang yang memiliki luas 750 Ha. Seiiring dengan bertambahnya pengetahuan sehingga diharapkan akan meeningkatnya pula kemandirian 
keluarga dan masyarakat dalam bidang kesehatan terutama peningkatan higiene dan sanitasi cuci tangan pakai sabun sehingga dapat meningkatkan derajat kesehatan masyarakat.

\section{PEMBAHASAN}

Perilaku Hidup Bersih dan Sehat (PHBS) adalah semua prilaku kesehatan yang dilakukan atas kesadaran sehingga anggota keluarga atau keluarga dapat menolong dirinya sendiri di bidang kesehatan dan berperan aktif dalam kegiatan-kegiatan di masyarakat.

Tujuan diadakannya usaha higiene dan sanitasi adalah untuk encegah timbulnya penyakit dan keracunan serta gangguan kesehatan lain sebagai akibat dari adanya interaksi faktor-faktor lingkungan hidup manusia (Kampunu, 2012).

Sasaran dalam PHBS yaitu terciptanya rumah tangga yang sehat, dalam hal ini cuci tangan pakai sabun.
Cuci tangan pakai sabun merupakan hal kecil namun dapat berdampak besar bagi kesehatan manusia.

Setelah

terlaksananya

Hal| 117

pengabdian masyarakat ini diharapkan adanya peningkatan, kemampuan, serta peran aktif PKK, Dasawisma dan Masyarakat tentang higiene dan sanitasi cuci tangan pakai sabun. Untuk melihat peningkatan dan pengetahuan masyarakat setelah dilakukannya penyuluhan menggunakan model partisipatif diadakan pemberian beberapa pertanyaan untuk mendeskripsikan hasil secara kualitatif.

Deskripsi olah data jawaban responden tentang perilaku penduduk di wilayah Kelurahan Kebun Bunga Kecamatan Sukarami Kota Palembang dalam menerapkan higiene dan sanitasi cuci tangan pakai sabundi pemukiman penduduk pada 336 responden terhadap 6 item pertanyaan dengan karakteristik responden berdasarkan umur yang lebih dominan yaitu terdapat pada dewasa akhir berusia 4665 tahun sebanyak (41\%). Berdasarkan 
pendidikan lebih dari separuh responden berpendidikan SMA yaitu sebanyak $(41,1 \%) \quad$ berdasarkan pekerjaan, lebih dari separuh ibu bekerja sebagai IRT (Ibu Rumah Tangga) sebanya $(65,2 \%)$.

Histogram presentase jawaban perilaku penduduk tentang higiene dan sanitasi dalam menerapkan cuci tangan pakai sabun setelah dbagikan kuesioner 6 item pertanyaan yang diberikan kepada 366 responden di Kelurahan Kebun Bungan Kecamatan Sukarami Kota Palembang dapat dilihat pada Gambar 1 berikut.

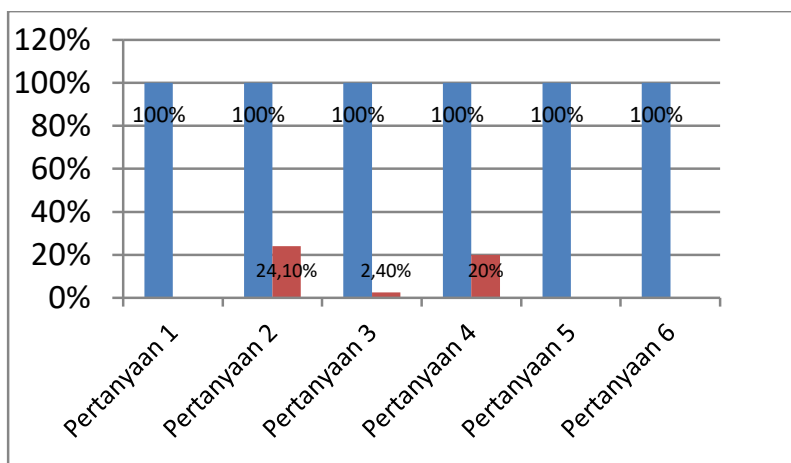

Gambar 1. Histogram Presentase Perilaku Higiene dan Sanitasi Cuci Tangan Pakai Sabun di Kelurahan Sukarami Kecamatan Kebun Bungan Kota Palembang

Berdasarkan Gambar 1. Menunjukkan bahwa presentase dari 6 item pertanyaan yang diberikan kepada 336 responden di wilayah Kelurahan Kebun Bunga Kecamatan Sukarami Kota Palembang, presentase terbesar Hal| 118 terdapat pada semua pertanyaan dengan jumlah presentase 100\% yang artinya masyarakat sudah memahami bahwa untuk mencuci tangan pakai sabun dengan benar diperlukan air yang bersih dan mengalir juga tremasuk sabun apapun itu jenis abun yang digunakan seperti sabun biasa, sabun antiseptic, atau sabun cair. Sedangkan presentase terkecil yaitu terdapat pada pertanyaan nomer 3 dengan dua jumlah presentase, presentase pertama 100\% dan presentase kedua 2,4\% pada wastafel, hal ini menunjukkan bahwa pada pertanyaan 3 lokasi untuk mencuci tangan terkecil yaitu di wastafel tetapi di sini respoden juga memanfaatkan kamar mandi, tempat cuci piring dan juga dapur untuk mencuci tangan. Artinya responden sudah pintar dalam memanfaatkan lokasi untuk mencuci tangan pakai sabun. Kurangnya 
fasilitas untuk mencuci tangan juga mempengaruhi responden dalam menerapkan higiene dan sanitasi cuci tangan pakai sabun dalam kehidupan sehari-hari. Dengan demikian fasilitas yang ada akan mendukung responden untuk mempraktikan cuci tangan pakai sabun seperti air bersih yang mengalir, sabun untuk mencuci tangan, lap atau pengering, dimana ketersediaan fasilitas yang mencukupi akan mendukung responden untuk mempraktikan cuci tangan dengan benar.

Berdasarkan butir soal nomer 1, "Apakah ibuu memakai sabun pada hari ini atau kemarin?" presentasi jawaban ya 100\% sedangkan jawaban tidak $0 \%$ menunjukkan bahwa responden memiliki pengetahuan yang sangat baik tentang cuci tangan pakai sabun, tingkat pengetahuan yang sangat baik tentang cuci tangan pakai sabun tersebut dapat menjadikan responden untuk berfikir betapa pentingnya cuci tangan pakai sabun untuk membantu menghilangkan atau membunuh kuman penyebab penyakit, dan melepaskan kotoran, lemak, atau minya dari kulit. Dari survey yang dilakukan keseluruhan responden Hal| 119 dengan cepat menjawab bahwa mereka memakai sabun pada hari ini atau kemarin. Artinya responden telah menjadikan sabun salah satu kebutuhan yang harus dipenuhi untuk menjaga kesehatan, esponden juga menjawab menggunakan sabun dapat menjadikan tubuh harum, segar dan bersih.

Berdasarkan butir pertanyaan soal nomer 2, “Untuk apa saja sabun digunakan oleh anggota keluarga?". Dilihat bahwa presentase mandi 100\%, memandikan anak 24,1\%, menceboki anak 24,1\%, mencuci tangan sendiri $100 \%$, mencuci tangan anak 24,1\%, mencuci peralatan minum, memasak dan minum 100\%, dan mencuci pakaian $100 \%$. Hal ini menunjukkan bahwa secara keseluruhan responden telah mengetahui kegunaan sabun dalam mencuci tangan. Mencuci tangan menggunakan air saja tidaklah cukup 
untuk melindungi seseorang dari kuman penyebab penyakit yang merugikan kesehatan, mencuci tangan dengan sabun merupakan salah satu cara yang paling efektif untuk mencegah kuman penyebab penyakit seperti diare, ISPA, infeksi mata, cacingan dan infeksi kulit. Segala jenis sabun dapat digunakan untuk mencuci tangan baik itu sabun biasa, sabun antiseptic, ataupun sabun cair (Muflih, 2014).

Dalam pengabdian masyarakat dan pengamatan ini kebanyakan responden lebih memilih sabun antiseptic dibandingkan sabun biasa.

Pada dasarnya penggunaan sabun biasa kurang terjamin kebersihaannya karrena kuman yang menempel pada sabun biasa setelah mencuci tangan akan menular ke orang lain, hal ini disebabkan oleh penggunaan sabun yang bersamaan. Untuk mendapatkan hasil yang optimal, maka mencuci tangan haruslah dengan air bersih yang mengalir, baik itu menggunakan kran air atau disiram dengan gayung, menggunakan sabun yang standar, setelah itu dikeringkan dengan lap atau pengering.

Berdasarkan butir soal nomer 3, “ Hall 120 Dimana saja anggota keluarga biasanya mencuci tangan?". Presentase jawaban di kamar mandi sebanyak 100\%, di tempat cuci piring sebanyak $57,7 \%$, di dapur sebanyak $19 \%$, dan wastafel sebanyak 2,4\%. Hal ini menunjukkan bahwa secara keseluruhan responden mencuci tangan di kamar mandi, namun responden mencuci tangan tidak hanya di kamar mandi tetpi juga memanfaatkan tempat cuci piring, dapur, dan ada juga mencuci tangan di wastafel. Fasilitas yang ada akan mendorog seseorang dalam mempraktikan atau membiasakan cuci tangan pakai sabun yang baik dan benar. Fasilitaas ini meliputi air yang bersih dan mengalir, sabun untuk mencuci tangan dan lap atau pengering. Lokasi untuk mencuci tangan ini sebenarnya tidak terlalu penting tetapi yang mempengaruhi dalam mencuci tangan ini yaitu fasilitas 
yang mendukung dan kesadaran seseorang Dallam menjaga kesehatan, karena mencuci tanngan dengan sabun ini merupakan cara paling efektif untuk menjaga kebersihan dari kuman penyebab penyakit.

Berdasarkan butir soal nomer 4, "Kapan biasanya anggota keluarga mencuci tangan pakai sabun?". Dilihat bahwa presentase jawaban sebelum ke toilet 20\%, setelah menceboki anak $24 \%$, setelah buang air besar 100\%, sebelum makan $100 \%$, setelah makan $100 \%$, sebelum menyuapi anak 24,1\%, sebelum menyiapkan masakan 72,3\%, sebelum memegang hewan 55,1\% dan sebelum sholat $100 \%$. Hal ini menunjukkan bahwa secara keseluruhan responden telah mengetahui waktu tepat dalam mencuci tangan pakai sabun. Pentingnya membudayakan cuci tangan pakai sabun ini jugaberpengaruh bagi kesehatan balita, karena dalam pertanyaan ini menyangkut kebersihan dan kesehatan balita, maka dari itu responden dituntut untuk mengetahui waktu tepat untuk mencuci tangan pakai sabun misalnya sebelum menyuapi anak. Artinya responden tidak hanya Hal| 121 menjaga kebersihan dan kesehatan balitanya, jika kurangnya pengetahuan terhadap waktu penting cuci tangan pakai sabun ini membuat responden menjadi lalai terhadap kebersihan dan kesehatan balita karena dari kelalaian tersebut dapat menyebabkan balita terkena diare, ISPA, dan infeksi cacing, kulit dan mata.

Berdasarkkan pertanyaan butir soal nomer 5, “Amati: Apakah tersedia air untuk mencuci tangan?" dilihat bahwa hasil pengamatan ya 100\% dan tiadak $0 \%$. Hal ini menunjukkan bahwa secara keseluruhan ketersediaan air di dapur responden sudah sangat baik, namun air yang baik untuk mencuci tangan pakai sabun ini yaitu air yang bersih dan mengalir juga tidak berbau. Dari survey yang dilakukan ada beberapa RT yang air di dapurnya masih kurang baik untuk mencuci tangan yaitu RT 16, 56, dan 67 karena 
airnya masih berwarna kuning dan berkarat namun responden mengatasinya dengan cara diberi kaporit, diendapkan dan disaring. Air yang berwarna kuning dan berkarat ini kurang baik untuk kebersihan dan kesehatan, seperti pada RT 67 ini beberapa responden mengambil air dari lebak, hal ini disebabkan karena kondisi sumur yang biasanya digunakan untuk mandi, masak dan keperluan lainnya sudah kering dan juga tidak tersedia air ledeng pada RT 67 ini. Tidak tersedianya air ersih dapat berpengaruh pada pelaksanaan cuci tangan pakai sabun yang baik dan benar juga mempengaruhi dalam menjaga kebersihan dan kesehatan responden (Sopacua, dkk. 2011).

Berdasarkan pertanyaan butir soal nomer 6, "Amati: Apakah terllihat adanya sabun untuk mencuci tangan dan mencuci peralatan masak, makan dan minum?", dilihat bahwa hasil pengamatan ya $100 \%$, dan jawaban tidak $0 \%$. Hal ini menunjukkan bahwa secara keseluruhan sabun terlihat di dapur responden, artinya responden mempunyai pengetahuan yang sangat baik sehingga sabun tidak hanya Hal| 122 digunakan untuk mencuci peralatan masak, makan dan minum. Segala jenis sabun dapat digunakan untuk mencuci tangan baik itu sabun biasa, sabun antiseptic, ataupun sabun cair.

Dengan demikian dari presentase perilaku penduduk tentang higiene dan sanitasi dalam menerapkan cuci tangan pakai sabun diatas dapat dikatakan bahwa prilaku masyarakat sudah sangat baik. Meskipun demikian responden harus lebih memahami kegunaan dan waktu penting Dalam mencuci tangan pakai sabun, karena dalam hal ini bukan hanya menjaga kebersihan dan kesehatan diri responden sendiri tetapi kebersihan dan kesehatan anggota keluarganya terutama balita karena balita masih bergantung pada responden. Segala jenis sabun dan fasilitas juga sangat berpengaruh dalam mencuci tangaan pakai sabun ini, namun yang lebih 
penting yaitu tersedianya air bersih mengalir baik itu dari kran air atau menggunakan gayung. Menurut Geria (2015), semakin baik ketersediaan sarana cuci tangan pakai sabun (CTPS) maka akan semakin baik pula untuk melakukan kebiasaan cuci tangan pakai sabun (CTPS) pada responden (Ibu rumah tangga) untuk menghindari berbagai penyakit seperti diare, ISPA, Infeksi cacing, mata dan kulit.

\section{SIMPULAN}

1. Pengabdian masyarakat ini menunjukkan adanya peningkatan higiene dan sanitasi cuci tangan pakai sabun.

2. Responden menyadari bahwa dengan mencuci tangan pakai sabun dapat mencegah timbulnya berbagai penyakit.

3. Responden telah memahami dan mengetahui kegunaan dan waktu penting tentang sanitasi cuci tangan pakai sabun.

\section{KEPUSTAKAAN}

Elytha, 2009. Survey Rumah Tangga PHBS di Kota Bukit Tinggi Tahun 2006. Jurnal Kesehatan Masyarakat. Vol 3, No. 2.
Geria, 2015. Hubungan Pengetahuan, Sikap, dan Ketersediaan Sarana dengan Kebiasaan Cuci Tangan Pakai Sabun untuk Mencegah Diare, ISPA pada Ibu Rumah Tangga di Kelurahan Ampenan Tengah Kota Mataram. Hal| 123 Jurnal Media Bina Ilmiah. Vol. 9, No. 1.

Kampunu, Jumiati. 2012. Hubungan Hygiene Penjamah Makanan dengan Keberadaan Bakteri Escherchia coli pada Sambal di Kantin di Lingkungan Asrama Mahasiwa Nusantara UNG. Skripsi tidak diterbitkan. Gorontalo. FAkultas Ilmu-Ilmu Kesehatan dan Keolahragaan Universitas Negeri Gorontalo.

Kushartant, 2012. Beberapa faktor yang Mempengaruhi Perilaku Cuci Tangan Pakai Sabun (CTPS) Studi di Sekolah Dasar Negeri Brebes 3 Tahun 2012. Tesis tidak diterbitkan. Diponegoro. Program Pasca Sarjana Universitas Diponegoro.

Megaria, dkk. 2013. Hubungan antara Perilaku Cuci Tangan Pakai Sabun dengan Terjadinya Diare pada Anak Usia Sekolah di SD Gmim Dua Kecamatan Tareran. Jurnal Keperawatan. Vol 1, No.1.

Muflih, 2012. Hubungan Pengetahuan Ibu terhadap Perilaku Cuci Tangan Pakai Sabun (CTPS) sebagai Pencegahan Diare pada Balita. (Online), (http://Journal.respati.ac.id/index.php/ ilmukeperawatan/article/download/23 $\underline{1 / 205}$, diakses tanggal 4 Juni 2019).

Sopacua, dkk. 2011. Hubungan Akses Air Bersih dengan Perilaku Cuci Tangan PAkai Sabun pada Rumah Tangga yang Mempunyai Balita di Indonesia. Jurnal Manajemen Pelayanan Kesehatan. Vol 14, No.1. 